\section{RIZAL, SEX AND CIVILISATION ${ }^{1}$}

\section{Raquel Reyes $^{2}$}

\begin{abstract}
This essay focuses on the work of the Filipino ilustrado, José Rizal, and his interest in the prevailing debate over whether the sexual behaviour of a culture reflects its level of civilisation. Spanish apologists for colonial rule had persistently argued that the Filipinos remained in many ways a backward and primitive people and delighted in alleging in support of their case that lasciviousness and promiscuity were widespread in the Philippines. These allegations caused deep offence to Rizal and his fellow propagandistas, who wanted, as a matter of patriotic honour, to repudiate such colonialist slurs. Through an examination of a selected sample of Rizal's annotations to Antonio de Morga's Sucesos de las Islas Filipinas, the author explores the ways in which Rizal sought to prove the civilized nature of his people through the assertion of female sexual chastity and sexual honour.
\end{abstract}

In the introduction to his famous work Psychopathia sexualis, the German psychiatrist Richard von Krafft-Ebing affirmed that sexual life was the finest

\footnotetext{
${ }^{1}$ This essay is a slightly modified version of a chapter from my book Love, Passion and Patriotism: sexuality and the Philippine propaganda movement, 1882-1892 (Singapore and Seattle: University of Singapore Press and Washington University Press, 2008)

${ }^{2}$ Research Fellow, Department of History, School of Oriental and African Studies, University of London
}

measure for determining the degree to which a culture could be called civilised. Primitive societies, he observed, were characterised by 'gratification of the sexual instinct' being 'the primary motive in man as well as in beast'; by men and women having sexual intercourse openly and unashamed of their nakedness; and by a relatively low value being placed on women's 'virginity, chastity, modesty and sexual fidelity' (Krafft-Ebing 1998:2).

Woman in uncivilised societies was the "common property of man, the spoil of the strongest and mightiest....a "chattel", an article of commerce, exchange or gift, a vessel for sensual gratification, an implement for toil." Certain "savage races" illustrated this uncivilised condition most strikingly, and the very best examples, in Krafft-Ebing's opinion, were the "Australasians, Polynesians, (and) Malays of the Philippines" (Krafft-Ebing 1998:1).

Rizal lived in Germany in 1886-87 and was well attuned to European scientific and intellectual currents. Possibly he was aware of Krafft-Ebing's work, and certainly he was keenly interested in the wider debate over whether the sexual behaviour of a culture reflected its level of civilisation. Physicians and ethnographers, Rizal saw, were prone to categorise mankind into different physical types and to draw sweeping generalisations about how these types differed in their intellectual capacity, cultural attainment and refinement, personal morality and sexual behaviour. Rizal did not object in principle to generalisations of this nature, but he did object forcefully to their lack of discrimination. Emphatically, he did not accept any generalisations that attached imputations of primitiveness to Hispanized lowland Filipinos like himself. 
Krafft-Ebing's reference to the Philippines gave added currency to the notion that Filipinos could be classified as primitive on the basis of their reputedly unbridled sexual life. To understand his assertion it is instructive to trace its intellectual genealogy. Ultimately, we shall see, it rested on Spanish sources that the propagandistas saw as tainted by racial prejudice and imperial self-interest. Krafft-Ebing's footnote reveals his indebtedness to Heinrich Ploss, whose ambitiously titled magnum opus Das Weib in der Natur - und Volkerkunde first appeared in $1884 .^{3}$ Ploss in turn relied primarily on the works of three authors, all of whom Rizal later met: the Austrian Ferdinand Blumentritt ([1880] 1980) ${ }^{4}$; as well as the Germans Alex Schadenberg (1880:133) (who had studied the Negritos) and Fedor Jagor (1873 and 1880) (who had travelled widely in the archipelago).

Blumentritt in particular was a key source, especially his Versuch einer Ethnographie der Philippinen, which was published in 1882 - four years before the Austrian orientalist became acquainted with Rizal and the Filipino propaganda campaign.

\footnotetext{
${ }^{3}$ Undergoing numerous re-publications, the work was continued and revised after the author's death by his collaborators Max Bartels and Paul Bartels. In its final incarnation, published in 1935, Ploss's work expanded into three volumes which with the aid of numerous intimate illustrations 'dealt fully', its editor boasted, 'with those aspects of a woman's life which are little known even to gynaecologists.' (Bartels and Bartels, eds. 1935)

${ }^{4}$ Besides relying extensively on Blumentritt's Versuch einer Ethnographie, Ploss also consulted the same author's 'Der Ahnenkultus in. die religiosen Anschauungen der Malayen des Philippinen-Archipel', Mittheilungen. d.k.k. Geographie Gesellschaft in Wien, 2-3 (1882), pp.177ff.
}

Ploss repeated Blumentritt's observations that the Tagalogs of Luzon, notwithstanding their "higher civilisation and milder morals" in relation to the Negritos and "mountain tribes," manifested a pronounced lack of sexual modesty. Blumentritt had even gone so far as to say that the Tagalogs displayed a number of animal-like faculties. They were remarkably adept at manipulating their toes to pick up small objects, and they retained an acute sense of smell, especially the women, who were "able to find out whether the men nearby them are sexually excited or not" (Blumentritt 1980:34-35).' The excessive immorality and sensuality of the Tagalogs, Blumentritt affirmed, were part of the 'pagan legacy' that endured despite the evangelizing efforts of the Spanish friars.

In making these assertions, Blumentritt drew upon, and thereby gave added credence to, the travel observations of Francisco Cañamaque, a Spanish journalist and traveller whom the propagandistas would later energetically attack (Cañamaque 1877 and 1879). Immorality, Blumentritt gleaned from Cañamaque, was widespread both in Manila and in the countryside of the Tagalog region:

Virginity is not a virtue for the girls easily give themselves up to any of their lovers, and only a small number of them are still virgin when they are brought before the altar for marriage. Sexual intercourse, according to Cañamaque, is performed without any ceremony even in the streets. The same writer claims that fornication is also a children's vice. Cañamaque says that they are a people without any feeling of shame. Women and men 
especially in the provinces, allow themselves to be seen completely naked.

$$
\text { (Blumentritt 1980:46) }{ }^{5}
$$

Blumentritt, whose observations on the primitiveness of Filipino sexual life had influenced other German scientists like Ploss and Krafft-Ebing, had ultimately based his pronouncements on the casual travel notes of reactionary and racist apologists for Spanish colonialism.

Rizal never adequately confronted the degree to which this reliance on flawed sources in fact shattered the academic validity of Blumentritt's comments on Filipino social life and customs. Indeed, Rizal actually commended Blumentritt's ethnographic study, esteemed him as a scholar and, as is well known, struck up a personal friendship and correspondence with him. Nobody else in the world, Rizal even went so far as to say, was better qualified than Blumentritt to write the history of the Philippines.

When he failed to persuade Blumentritt to undertake this task, Rizal decided to tackle it himself, and in 1888-89 spent a number of months in London reading as many sources as he could find on Filipino society at the time of the Spanish conquest. He studied mainly in the Reading Room of the British Museum, where other readers during his visit included H. G. Wells, Rudyard Kipling, Eleanor Marx and Peter Kropotkin. Rizal's project was to build what cultural historian Resil Mojares has called 'a nationalist counter-narrative.' His overall

\footnotetext{
${ }^{5}$ This passage is closely paraphrased by Ploss in Das Weib, vol.I, p.223.

${ }^{6}$ British Museum Signature of Readers, 4 June 1887-11 October 1888. Unpublished volume, British Museum Reading Room archive.
}

thesis was that the pre-Hispanic indios had attained a high level of civilisation, and that this civilisation had been corrupted and destroyed as a result of Spanish conquest. As a vehicle for advancing this thesis, he chose to annotate one of the fullest and most objective accounts by a secular Spaniard, Antonio de Morga's Sucesos de las islas Filipinas, which had first been published in 1609. Rizal regarded the author as 'a learned explorer' who possessed 'nothing of the superficiality and exaggeration so peculiar to the Spaniards'. ${ }^{7}$ Equally important, he had been a high-ranking colonial official, and not a friar; he regarded the religious orders, indeed, as a source of lamentation and trial (Cummins 1972:4). Rizal published his edition of the Morga in Paris in 1890 (Rizal 1890a).

When working on his annotations, Rizal mined an array of early Spanish missionary chronicles as well as the travel accounts of other Europeans. Throughout the work, he highlighted and elaborated the points Morga made about the material and cultural attainments of pre-colonial society and reflected on their subsequent decline, destruction and debasement wrought by Spanish colonization. $\mathrm{He}$ dwelt on the prosperity of the Islands' agriculture and commerce, on their flourishing mining, shipbuilding and metalworking industries and on the well-

\footnotetext{
${ }^{7}$ Josè Rizal (London) to Ferdinand Blumentritt, 17 September 1888, RizalBlumentritt Correspondence, (Manila: Jose Rizal Centennial Commission, 1961), p.201. Antonio de Morga obtained his doctorate in canon law from the University of Salamanca in 1578. He was appointed to Manila as lieutenant governor in 1593 and five years later became a judge in the Supreme Court of the colony, the Audiencia.
} 
developed material culture and literacy of the pre-Hispanic inhabitants.

On matters of sex, however, what Rizal read in the Morga and the other early Spanish sources he found in the British Museum, presented a major problem. These early chronicles, he discovered, were replete with detailed descriptions of a variety of sexual behaviour, relationships and socially sanctioned practices that did not at all accord with what $19^{\text {th }}$ century scientific thinking would classify as civilised. They foreshadowed, in other words, the Spanish accounts that Rizal and his fellow propagandistas so vehemently attacked as insulting and false. The early chroniclers recited a litany of aberrations, perversions and mortal sins. They witnessed fornication, adultery, forms of polygamy, polyandry, concubinage, incest and what they called the 'sin against nature', in other words sodomy, which encompassed homosexual, heterosexual and bestial anal penetration. Sex, to the pre-colonial natives, evidently entailed much more than the propagation of the species. It was also enjoyed, much to the chroniclers' disgust, purely in the pursuit of carnal pleasure.

Predictably, the blame for this sorry state of affairs was laid by the Spanish chroniclers principally on the native women. The mujer indigena, they repeatedly remarked, was lascivious and unchaste; her sexual desires shockingly unruly and unmanaged. Miguel de Loarca's observation in 1582 was typical:

The women are beautiful, but unchaste. They do not hesitate to commit adultery, because they receive no punishment for it...[They are] extremely lewd, and they even encourage their own daughters to a life of unchastity; so that there is nothing so vile for the latter that they cannot do it before their mothers, since they incur no punishment.

(Loarca 1582:1618)

How then was Rizal to deal with such accounts? As we noted, he subscribed fully to the notion then prevalent in medical and scientific thinking, that the degree of civilisation a society had attained should be measured as much, if not more, by its sexual life as by its material wealth and high culture. Evidence of lasciviousness in the preHispanic archipelago was directly at variance with the nationalist 'counternarrative' he wanted to construct.

Throughout his combative annotations, Rizal tried manfully to defend the preconquest indio women from the calumnies of the Spanish chroniclers. The allegations of women's inordinate sexual appetite were persistent, and Rizal found it difficult to refute them as decisively as he would have liked. He challenged the allegations wherever he could, but where he could not, he found it difficult to maintain a coherent and plausible argument. Where he felt in clear conscience unable to dispute the evidence he often tried to fudge the issue - by conflating the past and the present, by digression, or, predictably, by making women's fondness for sex more palatable by linking it explicitly to the desire to reproduce. The reason there was little sexual modesty, he tried to claim in one annotation, was because native women 'saw nothing sinful in the act of reproducing the species.'

Rizal clearly found dealing with the historical evidence of the indio women's 
strong libido a painful struggle. At some points he would seek to challenge the evidence, to excise the sensuality inherent in the image of the pre-colonial native woman portrayed by Morga and replace it with an undebauched, moral, if not prudish representation. His fellow propagandista Pedro Paterno, he noted, had already "brilliantly refuted" the assertion of Morga and other chroniclers that young native men and women had been sexually "incontinent" by citing other texts and testimonies that held the contrary. There were also numerous instances in the chroniclers' accounts, said Rizal, of young women who so prized their chastity that they preferred death rather than surrender themselves to Spanish conquistadores and officials.

To substantiate his case, Rizal marshalled whatever evidence he could find that testified to the modesty, domesticity and high repute of pre-Hispanic women. Quoting from the 1605 account of the Jesuit missionary Pedro Chirino, whose portrayal of native society was much more sympathetic than that of most early chroniclers, he related that even when bathing women kept their bodies 'bent and...immersed in the water until the throat, [taking] the greatest care not to be seen, though there may not be anybody who can see them'(Rizal 1890a:262). In all places they were 'circumspect and careful in covering their bodies with extreme modesty and bashfulness'(Rizal 1890a:288). Marriage in pre-Spanish times, Rizal contended, was a union of equals, more egalitarian in fact than both the traditional European dowry system and more contemporary European customs. The Spanish chroniclers had disparaged the marriage and divorce customs they encountered, claiming they illustrated the amorality of native culture and a lack of respect for women, but in reality, contended Rizal, marriage had been a union of equals. Women were not forced into arranged marriages but could marry the husband of their own choice, showing that they enjoyed the same autonomy as men. The fact that there was no dowry system showed that bridegrooms did not regard their brides as heavy burdens, or yokes, but as companions and helpmates. As Rizal noted:

The Tagalog wife is free and respected, she manages and contracts, almost always with the approval of her husband, who consults her about all his acts. She is the keeper of the money. She educates the children... She is not the European woman who marries, and loses her name, rights, liberty... limited to reign over the salon, to entertain guests, and to sit at the right of her husband.

(Rizal 1890a: 53)

Filipino women, Rizal asserted, brought to the domestic domain something far more valuable than a dowry. They brought moral rectitude. The Filipina, he claimed, was able to restrain her passions, to channel her love and energy into domestic life and to inject 'economy' into the 'irregular life of a bachelor'. She was responsible for the education of her children, independently conducted financial business as she saw fit, and her husband sought her counsel and respected her decisions. Highlighting customs of bilateral inheritance and divorce, Rizal pointed to a historical legacy of gender equality and then constructed an image of enlightened, civilised femininity. The preconquest indio woman thus became a positive signifier - she was wise, prudent, 
nurturing, industrious and entrepreneurial (Rizal 1890a: 263).

But, however much Rizal saluted the outward modesty of pre-Hispanic women, their equal standing with men, and their admirable domesticity after marriage, he could not lay to rest the vexed issue of their sexuality. Rizal had been guided by his patriotic desire to portray pre-Hispanic civilisation in the best light possible. But, as he later affirmed, he had not allowed himself to take liberties with the historical record. So far as the sexual habits of indio women were concerned, he admitted, he could not 'deny what I had found in the testimonies of all the authors' (Rizal 1890b: 504-507).

Unable to dispute what appeared to be incontrovertible, Rizal tried instead to explain and excuse, but his arguments, smooth when affirming gender equality, became conspicuously less assured. Again drawing on the writing of the Jesuit Chirino, Rizal related that the reported 'weakness' of indio women seemed to be rooted partly in superstitious belief. After death, it was said, women needed to cross a very dangerous river before they reached paradise, and the only bridge across the river was a narrow tree trunk. To get across safely they needed to be led by the hand of a lover they had known in their earthly life, and a lover in this context did not mean a husband.

No less strange was his response to the report of Morga that there had been men in indio society who were paid to deflower virgins before their marriage so that their husbands would then "not have to bother themselves with overcoming their bride's maidenhood" (Rizal 1890b: 309). Constrained by lack of evidence in disputing the truth of these reports, Rizal resorted instead to question their credibility by drawing a tortuous, whimsical analogy between virginity and ballroom dancing. If pre-marital ballroom dancing were considered a sin like premarital sex, he jested, then young men would not want expert dancers for their brides; rather they would seek those women whose dancing was most inept, who would tread clumsily on their feet (Rizal 1890b: 309-310).

Plainer and more forthright was Rizal's rejoinder to Morga's assertion that indio women loved money so much they would yield themselves up easily for a price (Rizal 1890a: 263). To this, Rizal responded that prostitution was found everywhere in the world. Europe itself, now so self-satisfied with its morality, he noted, had a long history of sexual licentiousness, of worshipping the 'cult of Venus, Priapus, Bacchus etc... of orgies and Bacchanalia... of prostitution in Christian Europe, and above all in the Rome of the popes'. In this matter, he rightly said, "no nation can cast the first stone." $\mathrm{He}$ insisted, nevertheless, that whatever the excesses of the past, "the Filipinas of today have no reason to blush before the women of the most chaste nations of the world" (Rizal 1890a: 263).

Rizal believed firmly in the need for moral rules, but wanted them based on reason rather than on 'pagan' superstition or the teachings of an obscurantist Church. Other ancient peoples, he observed, had likewise regarded sex in terms of biological imperatives and natural instincts. The ancient Jews, for example, had not prohibited the sexual act except when it was adulterous. "Only Christianity, he continued, had "made the act a mortal sin because...it saw everything carnal as corrupt, bad, like 
something from the devil, giving rise to that horror of the flesh that dominated the Cenobites, hermits...in the first centuries, a reaction of disgust perhaps at the laxity of ancient Rome and of all pagan society." But between carnality and the gloomy and barren "anti-naturalism" of the Christian zealots, between "excessive naturalism" and "excessive privation", Rizal argued, there was a middle ground that he described as "obedience to natural laws without adulterating them or frustrating the purposes that all things have" (Rizal 1890a: 289). For Rizal the attainment of this balance was the true mark of civilisation.

Yet according to historical sources, Filipinos seemed far too inclined to disobey and adulterate 'natural laws'. Especially troubling to Rizal was the recurrent mention of incest and sodomy. Morga's claim that incest was an "ordinary" practice, he sensibly countered as simply an exaggeration. Incest may not have been totally absent, he conceded, but again he argued that it was not so prevalent as in other places and times, as was testified by "the annals of the great peoples and families of Christian and devout Europe." Furthermore, Morga's comments reminded him of the slanderous scribblings of certain morally dubious Spanish hacks of his own day. "In order to assert such dirty stupidities", Rizal provocatively suggested, "it is necessary to have witnessed them, or believe oneself capable of doing the same if placed in the same circumstances" (Rizal 1890a: 307).

In his footnote on sodomy, Rizal was even more passionate. He saw sodomy as an 'abominable crime'. He believed it occurred either when men became 'disgusted by prostitution' and here he offered as examples the southern regions of Europe and China, or when "excessive privation", such as that imposed "in certain single sex convents and schools", compelled nature to adulterate itself by wandering down "mistaken paths" (Rizal 1890a: 308).

Morga had claimed that sodomy had become more widespread after the arrival of the Chinese. Much inclined to this vice, they had succeeded in contaminating indio men and women. Writing not long after one of the first and bloodiest massacres of the Chinese by the Spaniards in 1603, killings enthusiastically aided and abetted by the Tagalogs in Manila, Morga evidently continued to harbour a common, deep-seated Spanish prejudice (Kamen 2002: 208), and also (Retana 1909:475). ${ }^{8}$ Rizal also makes plain his own antipathy towards the Chinese:

Despite what Morga says and despite the fact that almost three centuries have already elapsed since then, the Filipinos continue abhorring this crime and they have been so little contaminated that in order to commit it the Chinese and other foreigners make use of their compatriots, of indio women and those who are their wives or of some miserable vagabond children.

(Rizal 1890a: 308-309)

There are two critical features to note in this diatribe against sodomy. Firstly, Rizal vehemently refutes Morga's claims of pervasive sodomitical practices amongst the Filipinos, and asserts that the relative

\footnotetext{
${ }^{8}$ Wenceslao Retana's annotations to the Morga also provide details of the Spanish laws enacted to prohibit sodomy in the colonies.
} 
"uncontamination" of the Filipino is a result of an historical hatred towards sodomy that continues even after three hundred years. Secondly, the "Filipinos" Rizal speaks of here refers not to indio men and women in general but exclusively concerns men. Rizal's stance against sodomy was all too plain. Ancient Filipino men vigorously resisted and were, so to speak, impenetrable. Thus, Chinese men and other sodomising foreigners had little choice but to use their fellow countrymen, native women and wretched stray children. Morga had thought sodomy was an abomination and Rizal agreed. Rizal's long footnote declared his disgust and refuted its incidence among indio men by stating that the practice was abhorred by them and hence contained, and therefore restricted to foreigners and their hapless weak partners.

Yet the criminality of this 'sin against nature' paled in comparison to a sexual practice which Morga regarded as even more shocking, wicked and depraved, not least because of its unfamiliarity to his European eyes. This was the custom of men in the Philippines, especially the tattooed people (Pintados) of the Visayas to pierce their penises. Credit for the invention of, and demand for, this bloody and devilish practice was unequivocally attributed by Morga to the unrelentingly lustful indio women:

The natives of the Islands of the Pintados, especially the women, are very vicious and sensual, and their malevolence has led them to invent lewd (torpe) ways of intercourse between women and men. The men have a custom that they practice from their youth onwards. They make a hole in their miembro viril, close to its head, and pass through it a device that resembles a serpent's head made of metal or ivory, which is then secured in place by material of the same substance. With this device they have intercourse with a woman, and are unable to withdraw long after coitus, for women are so addicted and find delight in it despite shedding much blood and receiving other injuries. These devices are called sagras...

(Morga [1609] 1890a: 145)

Morga had not been alone in documenting these painful penile piercings. Indeed, his was one of the later observations. The first European to record his fascinated, but horrified reaction to the penile implants and incisions so common in Southeast Asia was Antonio Pigafetta, the chronicler of Magellan's voyage of 1521. In Java, Pigafetta had heard the delicate sound of tinkling bells emanating from the penises of men who had come, on the pretense of urinating, to serenade their sweethearts with the melodious music they made by shaking their penises (Pigafetta 1523:169). But subtle music-making in Java was a far cry from the assortment of flesh-tearing wheels, stars, spurs and gold bolts as large as a 'goose quill' in use in the Philippines that Pigafetta scrupulously went on to detail (Pigafetta 1523: 167).

Rizal had made good use of Pigafetta's enthralling, richly detailed account and would have found it impossible to miss the Italian's startling descriptions of penile erotic surgery. But what was most remarkable about the numerous accounts given by the historical sources, was not the 
variety of devices for penis being used and their dispersion throughout Southeast Asia, nor the difficult techniques of piercing, which the aghast chroniclers were only too happy to relate to their readers in graphic detail. In fact, more striking still was the reason given by all the chroniclers to explain the punctures and insertions. Men endured the agony of penile operations and wore the devices, Pigafetta related, principally for the enhancement of female sexual pleasure: 'They say that their women wished it so, and that if they did otherwise they would not have communication with them.'

Morga' $s$ description of the Filipino penis perforations appears within a sequence of paragraphs that deal with pre-conquest sexuality in general — about the promiscuity of young people, sodomy, 'herbolarios y hechiceros' (herbalists and witch doctors), and the men whose task it was to deflower young women. All these topics provoked annotations from Rizal in which he plainly relished the opportunity to modify, correct and refute. How then did Rizal respond to Morga's account of penile mutilation? One would expect a footnote. But here Rizal's prolixity came to a conspicuous halt, his silence made more deafening by the long annotations on its flanks.

Rizal's silences in the Morga are rare occasions but telling ones, and such is the case with his silence on the subject of penile mutilation. The bulk of his historical sources had carried similar descriptions and more importantly, had similarly attributed the practice to female lasciviousness. Given the weight of the historical evidence that confronted him, we can only surmise that on this point he felt unable to refute Morga.

\section{References}

Bartels, Max and Paul Bartels (eds.). 1935. Woman: 10 a Historical, Gynaecological and Anthropological Compendium. Translated and edited by Eric John Dingwall. London: William Heinemann Medical Books Ltd.

Blumentritt, Ferdinand [1882]. 1980. An Attempt at Writing a Philippine Ethnography [Versuch einer ethnographie der Philippinen] Translated from the original German text by Marcelino N. Maceda (Marawi City: University Research Center, Mindanao State University.

Cañamaque, Francisco. 1877 and 1879. Recuerdos de Filipinas: cosas, casos y usos de aquellas islas, 2 vols. Madrid: Librería de Anllo y Rodriguez and respectively, Madrid: Librería de Simon y Osler.

Cummins, J. S. 1972 [Antonio de Morga] Sucesos de las islas Filipinas. Translated and edited by J. S. Cummins. Cambridge: Cambridge University Press.

Jagor, Fedor. 1873. Reisen in den Philippinen. Berlin:Weidmann.

Jagor, Fedor. 1880. Sexuelle abnormitaten bei den Bisayern, Philippinen. Verhandlungen der Berliner Gesellschaft fur Anthropologie, Ethnologie und Urgeschichte, 12: 90-1.

Kamen, Henry. 2002. Spain's Road to Empire: The Making of a World Power 1492-1763. London: Penguin. 
Krafft-Ebing, Richard von [1886]. 1998. Psychopathia Sexualis, with Especial Reference to the Antipathic Sexual Instinct. Translated by Franklin S. Klaf New York: Arcade Publishing.

Loarca, Miguel de [1582]. 1909.

Relacion de las Yslas Filipinas. In The Philippine Islands, 1493-1898, eds. by Emma H. Blair and James A. Robertson, Vol. V. Cleveland, Ohio: A. H. Clark.

Mojares, Resil. 2002. Waiting for Mariang Makiling: Essayss in Philippine Cultural History. Quezon City: Ateneo de Manila University Press.

Pigafetta, Antonio [1523]. 1906. The Voyage of Magellan: the Journal of Antonio Pigafetta. In The Philippine Islands, 1493-1898, eds. by Emma H. Blair and James A. Robertson, vol. V. Cleveland, Ohio: A. H. Clark.

Ploss, Herman Heinrich. 1884. Das Weib in der Natur- und Volkerkunde: Anthropologische Studien. Leipzig: Th. Grieben.

Ploss, Herman Heinrich, Max Bartels and Paul Bartels. 1935. Woman: An Historical, Gynaecological and Anthropological Compendium in Eric John Dingwall. London: W.Heinemann Itd.

Retana, Wenceslao. 1909. Sucesos de las islas Filipinas por el Dr. Antonio de Morga, nueva edición enriquecida con los escritos ineditos del mismo autor ilustrada con numerosas notas que amplien el texto y prologada extensamente por W. E. Retana. Madrid: Librería General de Victoriana Suarez.
Rizal, José. 1890a. Antonio de Morga, Sucesos de las islas Filipinas.Obra públicada en Mejico el ano de 1609, nuevamente sacada a luz y anotada por José Rizal, y precedida de un prologo del Prof. Fernando Blumentritt. Paris: Librería de Garnier Hermanos.

Rizal, José. 1890b. Una contestación a Don Isabelo de los Reyes. $L a$ Solidaridad, Vol. II, 31 October: 5047.

Schadenberg, Alex. 1880. Ueber die Negritos den Philippinen. Zeitschrift fur Ethnologie, $133 \mathrm{ff}$. 